\title{
CURRENT ACCOUNT DEFICIT AND ECONOMIC GROWTH IN ARMENIA
}

\author{
Arus Tunian $^{1}$ \\ V.N. Karazin Kharkiv National University (Ukraine) \\ arusik90@hotmail.com
}

\begin{abstract}
The article is devoted to the study of the problem of economic growth in Armenia. It is identified the nature of the balance of payments of the country, indicating a net debtor position, which leads to inherent deterioration of the international investment position. A small open economy of Armenia moves to a new phase of development, in the frame of the integration processes within the Customs Union and the Eurasian Economic Union of Russia, Belarus and Kazakhstan. One of the main characteristics of the Armenian economy vulnerability remains a negative balance in foreign trade, which continues to grow, despite the export growth. Economic growth is provided, as before, mostly due to the sale of raw materials - non-ferrous metals and metal ores, both in the primary as well as in the previous preprocessing. Estimating the econometric VAR models revealed that the negative current account impacts on GDP growth negatively.
\end{abstract}

\section{Keywords}

balance of payments; economic growth; GDP; econometric estimation; integration

\section{JEL Classification}

E20; F32

\section{Introduction}

A small open economy of Armenia moves to a new phase of development, namely to join the integration processes within the Customs Union and the Eurasian Economic Union of Russia, Belarus and Kazakhstan.

One of the main characteristics of the Armenian economy vulnerability remains a negative balance in foreign trade, which continues to grow, despite the export growth. Economic growth is provided, as before, mostly due to the sale of raw materials non-ferrous metals and metal ores, both in the primary as well as in the previous preprocessing.

The modern Armenian economy can be also characterized as the one with a high share of shadow economy (35-50\% of official GDP), capital outflow, and low attractiveness to foreign direct investment.

Due to the new geoeconomical challenges it is becoming vitally important to diagnose the quality of economic growth in Armenia, partly because the national economy is heavily dependent on diaspora foreign aid and has a total deficit of balance of payments.

\section{Theoretical and Empirical Overview}

In modern economic literature the issue of economic growth is among the priorities. R. Solow (1956) proposed that we begin the study of economic growth by assuming a

\footnotetext{
${ }^{1}$ PhD Student, Department of International Economic Relations
} 
standard neoclassical production function with decreasing returns to capital. Taking the rates of saving and population growth as exogenous, he showed that these two variables determine the steady-state level of income per capita.

According to the analytical report of Eurasian bank of development (2013), with the development of the national economy due to the expansion of domestic demand, Armenia is extremely interested in agreements that guarantee freedom of movement of labor and capital that provide stable funding the current account of balance of payments.

Research paper by Lanzafame (2013) states, that the balance of payments represents the ultimate constraint on long-run growth and give remarkable support to the Keynesian vision of economic growth as being demand-driven. Razmi (2010) emphasizes that positive trends in technological progress may hurt or help an economy that faces balance of payments constraints. The impact depends partly on the sector that the progress takes place in and partly on the structure of the economy. In other words, it is not just the direction of shocks to supply (or demand), but also the sectoral composition of these shocks that matters.

S. Ayvazyan, A. Bereznyatskyi and B. Brodsky (2014) using econometric models revealed the presence of "Dutch disease" in the economy of Armenia. Deslike from Russia, where such an economic behavior is due to the export of oil and gas, in Armenia it is happening due to labor migration.

Nevertheless, the impact of current account deficit on economic growth in Armenia still needs more investigation.

\section{Economic growth and Balance of payments in Armenia}

Armenia's economy has undergone a profound transformation since its independence in 1992. Sustained growth, ambitious reforms, as well as inflows of capital and remittances have created a market-oriented environment. However, the global financial crisis impacted significantly the market of the country (World Bank, Armenia Overview). According to the World Bank review the key challenge for the government is to mitigate the economic and social impacts of the global crisis for the midterm, while continuing policy and institutional reforms essential for recovery and long-term development. Increasing the economy's resilience to external shocks and creating new opportunities for development are important priorities.

The structure of Armenia's GDP in 2014 is divided as following: the service sector (64.0\%), the second position - agriculture (19.0\%), third place - industry (17.0\%).

In agriculture, the first position is crop (11.1\%), followed by - livestock (7.0\%), the third - fishing (0.9\%).

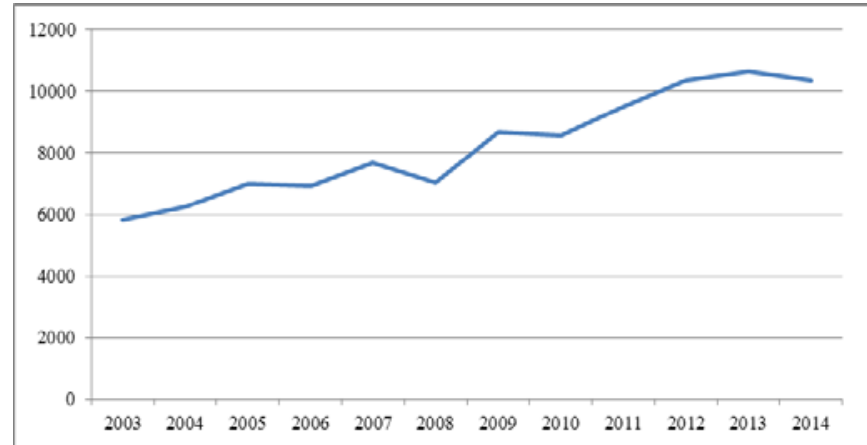

Figure 1 GDP of Armenia (mln. U.S. dollars)

Source: Central bank of Armenia Statistics 
Armenian GDP has a positive trend for economic growth during the whole period of observing (2003-2013). Double digit growth rates of pre-crisis period were replaced by a 4.0 percent rate after the crisis. Following a moderate 3.2 percent growth in 2013, but since 2014 we see the decline of $2.6 \%$, driven mainly by the regression in construction and slowdown in Russia. Besides low price level on the main ore (metal) raw materials, as well as the expected decline of domestic demand in Armenia. Such an economic behavior finds its reflection.

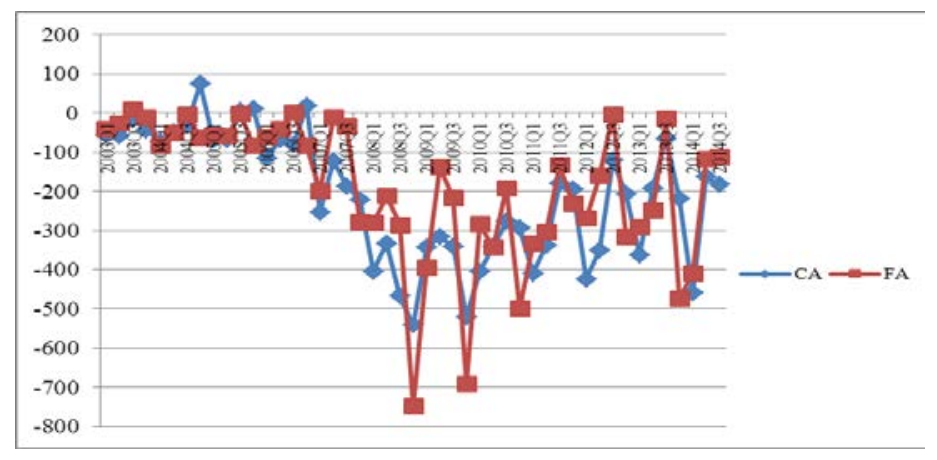

Figure 2 Balance of payments of Armenia (mln. U.S. dollars)

Source: Central bank of Armenia Statistics

A main feature of the balance of payments of Armenia is its overall deficit, indicating that the Armenian economy is a net borrower. It should be noted that dislike most of post-transitional economies, balance of payments Armenia has a significant deficit both in the current account and the financial account. The only account of the balance of payments of Armenia, which is positive - the capital account (but this account cannot balance the general equilibrium).

As we mentioned before, the basis for economic growth of the Republic of Armenia of recent decades is the export of goods and growing domestic demand as private consumption, which is supported by migrant remittances from abroad, primarily from Russia. Starting from 2004 the remittances has been growing steadily (Figure 3).

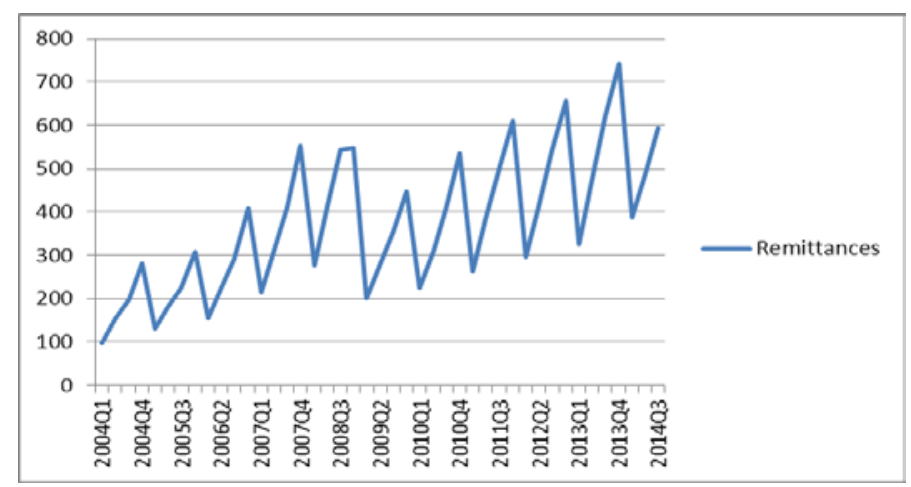

Figure 3 Inflow of Remittances by Balance of Payments (mil. U.S. dollars) Source: Central bank of Armenia Statistics

No less important in the case of Armenia is the state of the labor market. Since independence, the labor market in Armenia has experienced a profound shift under the influence of a systemic crisis in the early 1990s, economic and social reforms, 
sustained economic growth for more than 10 years - since the mid-1990s to 2008 (before the recent crisis, due to the sustained growth and then decline of the economy). However, the real unemployment rate remained constant at two-digit level: on average, about one in four economically active people was unemployed. This is partly the reason for the high labor migration.

\section{Methodology and model estimation}

We run unit root test for the time series. According to the tests for stationarity on a number of variables have yielded conflicting results, so to determine more accurately the order of integration time series we ran Phillips-Perron test.

Table 1 Unit root test

\begin{tabular}{|l|l|l|l|l|}
\hline \multicolumn{5}{|c|}{ Phillips-Perron test } \\
\hline & GDP & CA & FA & REMITTANCES \\
\hline $\mathrm{c}$ & $* * *$ & $*$ & $* * *$ & $* * *$ \\
\hline $\mathrm{ct}$ & $* * *$ & $* *$ & $* * *$ & $* * *$ \\
\hline $\mathrm{c}-\operatorname{diff}$ & $* * *$ & $* * *$ & $* * *$ & $* * *$ \\
\hline $\mathrm{ct}-\operatorname{diff}$ & $* * *$ & $* * *$ & $* * *$ & $* * *$ \\
\hline$* \mathrm{p}<0.10 ; * * \mathrm{p}<0.05 ; * * * \mathrm{p}<0.01 ;$
\end{tabular}

Source: EViews

We run the following model:

where:

$$
\text { GDP }=f(\text { CA, FA, REMITTANCES }) \text {, }
$$

CA - current account, mil. USD (quarterly data)

FA - financial account, mil. USD (quarterly data)

REMITTANCES - volume of remittances inflow, mln. USD (quarterly data)

Regression results from estimating of the equation using OLS method is reported in

Table 2.

Table 2 Regression model results

\begin{tabular}{|l|l|}
\hline \multicolumn{2}{|l|}{ Armenia } \\
\hline Variables & Regressors (OLS) \\
\hline GDP(-1) & $1.04^{* * *}$ \\
& $(15.72)$ \\
\hline CA(-1) & $-19.29^{* * *}$ \\
& $(-7.40)$ \\
\hline FA(-1) & $15.53^{* * *}$ \\
& $(6.90)$ \\
\hline REMITTANCES & $13.779^{* *}$ \\
& $(14.95)$ \\
\hline $\mathrm{R}^{2}$ & 0.85 \\
\hline DW & 1.89 \\
\hline Note: $* * *, * * * *$ imply significance at $1 \%, 5 \%, 10 \%$ levels respectively \\
t-statistic (in brackets) & \\
$\Delta-$ first difference operator & \\
\hline
\end{tabular}

The results from the OLS estimation show that: 
- the variables CA and FA become significant only with a time lag;

- remittances inflow to Armenia is one of the most significant factor that explain the structure of economic growth. If remittances increase in 1 unit, the GDP increases in 13,7. It shows that the Armenian economy is growing due to the internal demand supported by the money inflows of the working migrants abroad.

To check the stability of the models for Slovakia and Poland (Figure 4 and Figure 5), we run CUSUM test.
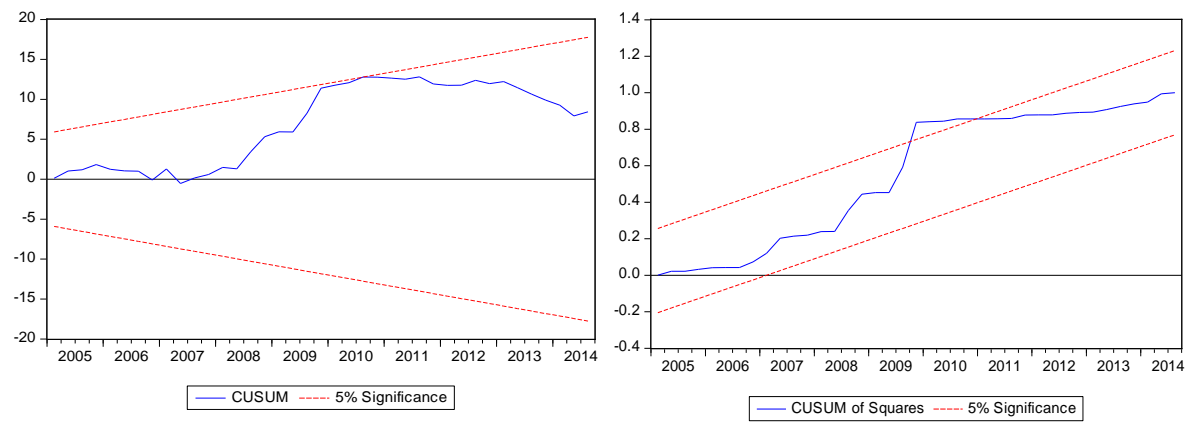

Figure 4 Cumulative Sum test (left) and CUSUM of Squares (right)

To test stability of coefficients, CUSUM and CUSUMSQ tests were performed. Figure 4 displays the CUSUM statistics plotted within $5 \%$ significance confidence bounds. Since the graph of this statistic remains within its confidence interval the null hypothesis of parameter constancy is not rejected. The CUSUM of Squares test (Figure 4) is a cumulative sum of squared residuals. According to Vogelvang (2005) the expectations of the CUSUM of Squares statistic run from zero at the first observation until the value of one at the end of the sample period. The test statistics are plotted with $5 \%$ confidence interval. Since the statistic does not hit the critical bound, the coefficients are stable over observed period of time.

The p-values of the autocorrelation (BG-test) and heteroscedasticity (BP-test) show that the null hypothesis of non-autocorrelation and homoscedasticity is not rejected. The output in Table 4 displays the coefficient of the lagged dependent variable (deposits) negative and significant, variables are cointegrated. The coefficient of adjustment (ECT) is negative and significant. It indicates how quickly variables restore equilibrium.

Table 3 Results from residual tests

\begin{tabular}{|l|l|l|l|}
\hline Armenia & $\begin{array}{l}\text { LM-test (Breusch-Godfrey) } \\
\text { Prob. Chi-Square }\end{array}$ & 0.21 & 0.16 \\
\hline
\end{tabular}

To evaluate the impact of current account deficit on economic growth we implement vector autoregressive modelling (VAR) that has the following theoretical view (2)

$$
y_{t}^{i}=a_{0}^{i}+\sum_{j=1}^{k} a_{1 j}^{i} y_{t-1}^{j}+\sum_{j=1}^{k} a_{2 j}^{i} y_{t-2}^{j}+\ldots+\sum_{j=1}^{k} a_{p j}^{i} y_{t-p}^{j}+\varepsilon_{t}^{i}
$$

Impulse response functions are useful for studying the interactions between variables in a vector autoregressive model. They represent the reactions of the variables to shocks hitting the system 

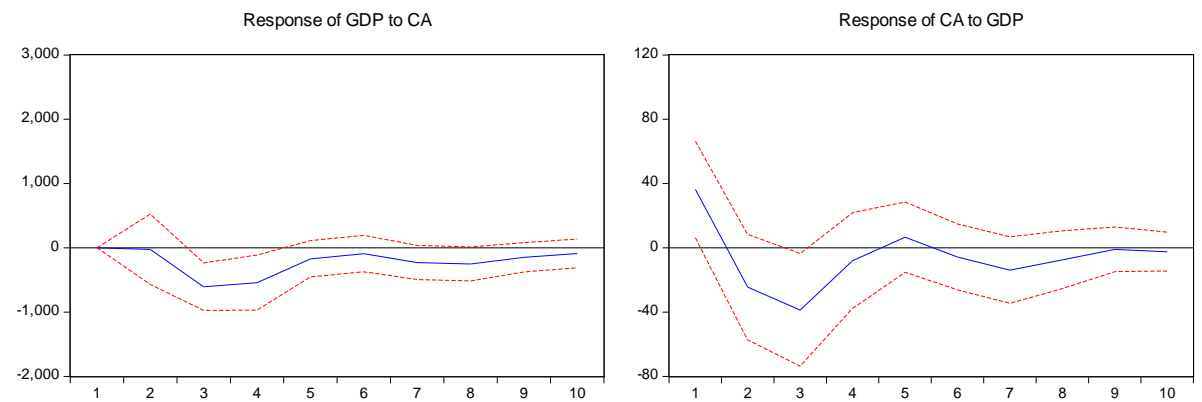

Figure 5 Impulse response function of GDP to current account Source: modeling in EViews

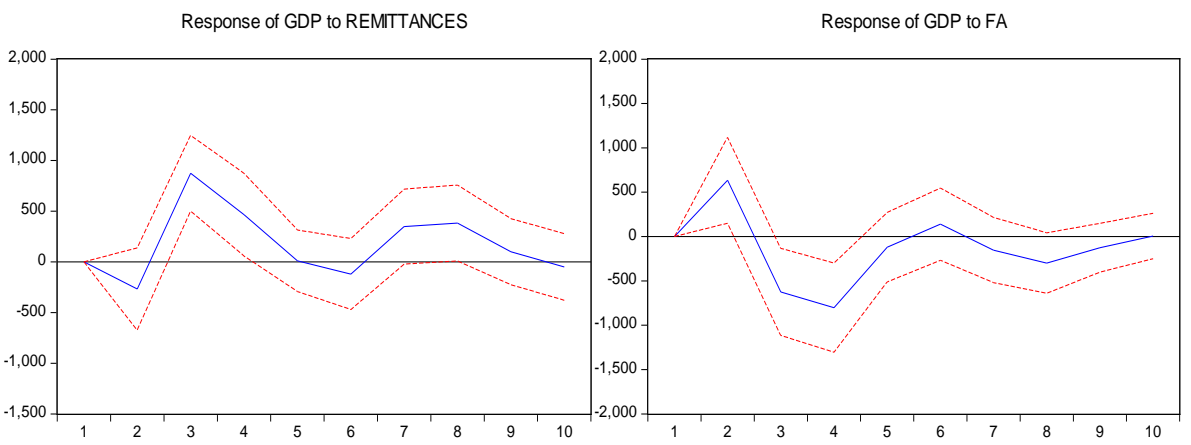

Figure 6 Impulse response function of GDP to remittances (left) and financial account (right)

Source: modeling in EViews

Thus, after running the impulse response function we can interpret it as following. Current account deficit prevent the Armenian GDP from positive trend both in shortterm and long-term period. Despite the remittances inflow, the current account remain negative and needs crucial steps in the frame of macroeconomic development. Incoming remittances play an important role in increasing the country's GDP. But the response functions shows that in long-term period the remittances may cause a decrease in GDP due to its high volatility.

Financial account has a negative impact in medium term and long-term periods.

International financial institutions have lowered forecasts of GDP growth in Armenia in 2015. So, in January, the IBRD (2015) has lowered its forecast for the economy of Armenia, expecting stagnation in 2015 instead of 3.5\% growth. The World Bank also downgraded the forecast, the bank predicts GDP growth in Armenia in 2015 at 3.3\% instead of the previous forecast of 5\%. According to the forecast of the Eurasian Bank of Development, GDP growth in Armenia in 2015 may reach 3.8\% instead of the previous forecast of $4.2 \%$.

The share of construction, trade, transport and services in GDP in 2011 was 60\%, while in the industry and agriculture accounts for only 40\%, whereas in 1996 the situation was diametrically opposed ( $40 \%$ and $60 \%$, respectively). This structure of the economy is highly dependent on the volume of transfers, which stimulates the final consumption of imported goods on the one hand (direct effect) and on the other and thus is possible to develop service industries, transport, construction and trade. In 
case of reduction of income transfers problems with the exchange rate, a reduction in imports and the collapse of these sectors, and as a result the financial sector can have very negative consequences for the country's economy.

\section{Conclusion}

From the above, the following conclusions. The period from 2013 can be called historical Armenia. In 2013, it was political events have shaped economic agenda. The presidential elections and the subsequent decision of Armenia's accession to the Customs Union were factors that determined the long-term political and economic course. This has led to closer Armenian economy depends on the macroeconomic situation in Russia.

To reduce the risks associated with its balance of payments and economic growth, the Armenian government would be advisable to absorb external risks. Reducing the debt to GDP ratio, easing tensions with Azerbaijan and improving relations with other neighboring countries could be the factors of further sustainable economic development in Armenia.

\section{References}

Ayvazian, S. A., Bereznyatsky, A. N., Brodsky, B. E. (2014), Dutch disease in the economies of Russia and Armenia, Applied Econometrics, 4(36).

Lanzafame, M. (2014), The balance of payments-constrained growth rate and the natural rate of growth: new empirical evidence, Camb. J. Econ, 38(4), 817838.

Razmi, R. (2010), Exploring the robustness of the balance of payments-constrained growth idea in a multiple good framework, Cambridge Journal of Economics, 1 of 23 doi:10.1093/cje/beq035.

Sachs, J. D. (1981), The Current Account in the Macroeconomic Adjustment Process, Working Papers, 796, National Bureau of Economic Research.

Solow, R. A. (1956), Contribution to the Theory of Economic Growth, The Quarterly Journal of Economics, 70(1), 65-94.

Vogelvang, B. (2005), Econometrics, FT Prentice Hall.

World Bank, Armenia Overview available at http://www.worldbank.org/en/country/armenia/overview. 